\title{
Anna Saczewska-Piotrowska
}

Uniwersytet Ekonomiczny w Katowicach

Katedra Metod Statystyczno-Matematycznych w Ekonomii

anna.saczewska-piotrowska@ue.katowice.pl

\section{BADANIE DYNAMIKI UBÓSTWA W POLSCE Z WYKORZYSTANIEM MODELI ANALIZY HISTORII ZDARZEŃ O CZASIE DYSKRETNYM}

\section{WSTĘP}

Analiza ubóstwa jest przeprowadzana najczęściej w ujęciu przekrojowym. Wzbogacenie analizy o wymiar czasowy pozwala odpowiedzieć na pytania dotyczące zmian w poziomie i zróżnicowaniu ubóstwa. W dłuższym okresie jednostki (osoby, gospodarstwa domowe, rodziny itd.) mogą wielokrotnie wchodzić do sfery ubóstwa i ją opuszczać. Analiza determinant tych zmian pozwala wskazać grupy gospodarstw domowych szczególnie zagrożonych wejściem do sfery ubóstwa oraz mających największe szanse na wyjście $\mathrm{z}$ tej sfery.

Głównym celem artykułu jest określenie determinant transformacji ubóstwa w Polsce w latach 2000-2011. W tym celu wykorzystano modele analizy historii zdarzeń o czasie dyskretnym, spośród których wybrano modele logitowe. Modele logitowe wejść (wyjść) do sfery ubóstwa szacowano w dwóch wariantach. W pierwszym uwzględniono liczbę lat spędzonych odpowiednio poza i w sferze ubóstwa. Natomiast w wariancie drugim uwzględniono dodatkowo wybrane cechy społeczno-ekonomiczne gospodarstwa domowego i głowy gospodarstwa.

W literaturze poruszającej problem wpływu czasu spędzonego w sferze ubóstwa i poza nią, odpowiednio na wyjście i wejście do tej sfery, panuje pogląd, że oddziaływanie czasu ma charakter negatywny. Według Heckmana (1981), doświadczenie ubóstwa $\mathrm{w}$ danym roku per se zwiększa ryzyko ubóstwa w następnym roku. Pionierzy badań trwałości ubóstwa, Bane i Ellwood (1986), podkreślali, że im dłużej jednostka jest uboga, tym mniej prawdopodobne, że opuści sferę ubóstwa. Temu powszechnemu poglądowi sprzeciwił się dopiero Foster (2007), który definiując ubóstwo trwałe, nie zwraca uwagi na ciągłość ubóstwa i przyjmuje, że wszystkie obserwacje dokonane w określonych momentach badania są niezależne. W niniejszym opracowaniu, weryfikując przypuszczenie o braku wpływu czasu spędzonego 
w sferze ubóstwa na wyjście z tej sfery, nawiązano do koncepcji Fostera. Analogiczną hipotezę weryfikowano w stosunku do wpływu czasu spędzonego poza sferą ubóstwa na wejście do tej sfery.

Uwzględnienie w modelach wybranych cech społeczno-ekonomicznych gospodarstwa i jego głównego żywiciela, ma umożliwić określenie ich wpływu na zmianę prawdopodobieństwa wejścia oraz wyjścia gospodarstwa do sfery ubóstwa. W pracy weryfikowano hipotezę, że prawdopodobieństwo wejścia do sfery ubóstwa jest wyższe w przypadku gospodarstw domowych, w których jest przynajmniej jedna osoba bezrobotna oraz w przypadku gospodarstw, których głowa ma mniej niż 60 lat. Sformułowano również hipotezę głoszącą, że prawdopodobieństwo wejścia do sfery ubóstwa jest niższe w przypadku gospodarstw zamieszkujących miasto oraz gospodarstw, których główny żywiciel jest mężczyzną i ma wykształcenie przynajmniej średnie.

\section{UBÓSTWO CHWILOWE I TRWAŁE}

Badanie dynamiki i trwałości ubóstwa wiąże się nie tylko z wyborem konkretnych mierników, ale przede wszystkim z przyjęciem odpowiednich założeń metodologicznych dotyczących pomiaru. Problemy pojawiają się już na etapie definiowania ubóstwa, określenia wskaźnika dobrobytu ekonomicznego, granicy ubóstwa oraz skal ekwiwalentności. Definicje ubóstwa można sprowadzić do jednej z następujących kategorii:

- ubóstwo to posiadanie mniej niż obiektywnie zdefiniowane absolutne minimum,

- ubóstwo to posiadanie mniej niż inni w społeczeństwie,

- ubóstwo to uczucie, że nie ma się wystarczająco dużo, aby sobie poradzić.

Zgodnie z pierwszą kategorią definicji ubóstwo jest absolutne (bezwzględne), zgodnie z drugą kategorią - relatywne (względne), natomiast według trzeciej kategorii może być absolutne, relatywne lub mieszane. Trzecia kategoria definiuje ubóstwo jako subiektywną sytuację, podczas gdy pierwsza i druga - jako obiektywną (Hagenaars i de Vos 1988).

Pomiar ubóstwa absolutnego polega na określeniu dochodów potrzebnych do zakupu dóbr i usług zaspokajających niezbędne potrzeby jednostki, a także jej rodziny. Zwolennikami badania ubóstwa w ujęciu absolutnym byli m.in. Charles Booth, Seebohm Rowntree i William Beveridge. Absolutną definicję ubóstwa przyjął w 1990 r. Bank Światowy. Koncepcja ubóstwa relatywnego zawiera w sobie odniesienie do sytuacji przeciętnej, czyli sytuacji innych grup w społeczeństwie. Pionierem podejścia względnego jest Peter Townsend. Jedną z pierwszych definicji ubóstwa relatywnego wprowadziła w 1975 r. Rada Wspólnot Europejskich. Definicja ta, w zmodyfikowanej postaci, aktualnie obowiązuje w Unii Europejskiej.

Drugi zaprezentowany podział, to podział ubóstwa na obiektywne i subiektywne. W ujęciu subiektywnym oceny poziomu zaspokojenia potrzeb dokonują same badane 
jednostki (osoby, rodziny, gospodarstwa domowe). Natomiast w przypadku ujęcia obiektywnego, ocena poziomu zaspokojenia potrzeb badanych jednostek jest dokonywana niezależnie od ich osobistych wartościowań (Panek i in. 1999: 11). Prekursorami podejścia subiektywnego byli Brian Abel-Smith i Peter Townsend (1965), natomiast najbardziej znane definicje ubóstwa subiektywnego zostały wprowadzone w pracy napisanej pod kierunkiem Goedharta (Goedhart i in. 1977).

Jednym z najczęściej spotykanych w literaturze przedmiotu podziałów ubóstwa, oprócz wyżej zaprezentowanych, jest podział na klasyczne i wielowymiarowe. W podejściu klasycznym identyfikacja ubogich opiera się jedynie na kategoriach pieniężnych (przez pryzmat dochodów lub wydatków). Ubóstwo w ujęciu wielowymiarowym utożsamiane jest natomiast nie tylko z poziomem dochodów (lub wydatków) ujmowanym w formie monetarnej, ale również z brakiem możliwości zaspokojenia pewnych potrzeb wynikających zarówno z niewystarczających dochodów, jak i zasobów materialnych (np. dobra trwałego użytku, mieszkanie itd.) ocenianych w formie niemonetarnej (Panek 2011:40). Zwolennikiem podejścia wielowymiarowego jest m.in. noblista Amartya Sen.

Istotną klasyfikacją ubóstwa, z punktu widzenia niniejszego opracowania, jest podział na ubóstwo chwilowe i chroniczne. Ubóstwo chwilowe jest oceniane na podstawie informacji przekrojowych, uzyskanych $\mathrm{w}$ danym momencie. Ocena, czy ubóstwo ma charakter chroniczny, wymaga przeprowadzenia analizy $\mathrm{w}$ ujęciu dynamicznym. $\mathrm{Z}$ tego powodu ubóstwo trwałe bywa interpretowane jako „Szczególny przypadek ubóstwa wielowymiarowego, w którym czas jest dodatkowym - poza dochodem (konsumpcją) - wymiarem uwzględnianym w analizie" (Topińska 2008).

Trwałość ubóstwa można rozpatrywać we wszystkich skalach analizy. W skali makro oznacza po prostu występowanie biedy w danym społeczeństwie w pewnych okresach. Historia wskazuje, że jest to zjawisko społeczne, występujące odwiecznie i powszechnie, choć zmienne w zasięgu i głębokości. Przy pewnym natężeniu tych cech staje się ono kwestią społeczną i wymaga społecznej interwencji. Trwałe ubóstwo w mezoskali to enklawy biedy w miastach i na wsi, integrujące się wewnętrznie na bazie poziomu i stylu życia oraz kultury odrębnej od reszty społeczeństwa, stylu nierzadko dziedziczonego z pokolenia na pokolenie, prowadzącego do wykluczenia społecznego i powstawania tzw. underclass ${ }^{1}$. Trwałe ubóstwo w skali mikro to bardzo szeroki wachlarz sytuacji: od ograniczonych możliwości ,wiązania końca z końcem” do przypadków zagrażających biologicznemu przetrwaniu, w których nieprzerwana trwałość biedy jest prawdziwą tragedią indywidualną o dalekosiężnym znaczeniu społecznym (Morecka i Styrc 2008).

Problematyka ubóstwa trwałego pojawia się w opracowaniach naukowych, jednakże nie jest ona zbyt często uwzględniana w analizach. Jednym z powodów jest

1 Pojęcie underclass wprowadził Gunnar Myrdal, zaliczając do underclass jednostki charakteryzujące się deprywacją warunków materialnych (ekonomicznych) i marginalizacją w ramach stosunków społecznych (Myrdal 1963). 
brak odpowiednich informacji statystycznych. Analiza ubóstwa długookresowego wymaga danych panelowych, obejmujących co najmniej dwa okresy obserwacji warunków życia tej samej próby jednostek. Jednak coraz bogatsze bazy danych, zawierające panele gospodarstw domowych, umożliwiają badania trwałości ubóstwa. Koncepcje oraz wyniki badań ubóstwa długookresowego omawiają w swoich pracach m.in. Bane i Ellwood (1986), Rodgers i Rodgers (1993), Jalan i Ravallion (1998), Hulme i Shepherd (2003), Thorbecke (2003), Betti i Verma (2004), Aaberge i Mogstad (2007). Wyniki badań ubóstwa trwałego w Polsce przedstawiono m.in. w pracach: Okrasa $(1999,2000)$, Panek (2001), Topińska (2005), Diagnoza spoteczna $(2006,2007,2009,2012)$.

Wybór określonej definicji implikuje określony sposób pomiaru ubóstwa. Przyjmując definicję ubóstwa np. w ujęciu relatywnym, dysponujemy pewnym wachlarzem możliwości wyboru granicy ubóstwa czy skal ekwiwalentności.

Ze względu na ograniczenia dotyczące objętości opracowania, problemy metodologiczne pomiaru ubóstwa nie będą omawiane w sposób bardziej szczegółowy. Ich opis można znaleźć w literaturze przedmiotu zarówno zagranicznej, np. (Hagenaars i van Praag 1985), (Atkinson i in. 2002), jak i krajowej (Panek 1999, 2011).

\section{WYBRANE METODY OCENY TRWAŁOŚCI UBÓSTWA}

Dysponując informacją, które gospodarstwo domowe ${ }^{2}$ jest ubogie, można przejść do badania dynamiki i trwałości ubóstwa. Zmiany w sferze ubóstwa są często określane na podstawie stóp ubóstwa liczonych odrębnie dla każdego badanego okresu. W 1984 r. Foster, Greer i Thorbecke zaproponowali klasę mierników ubóstwa, którą można zdefiniować następująco (Foster i in. 1984):

$$
P_{\alpha}\left(\mathbf{y}, y^{*}\right)=F G T(\alpha)=\frac{1}{n} \sum_{i=1}^{q}\left(\frac{y^{*}-y_{i}}{y^{*}}\right)^{\alpha}
$$

gdzie:

y - wektor dochodów,

$y^{*}$ - granica ubóstwa,

$\alpha(\alpha \geq 0)$ - parametr miernika,

$n$ - liczba gospodarstw domowych,

$q$ - liczba ubogich gospodarstw domowych (mających dochód nie większy od wyznaczonej granicy ubóstwa).

2 Omawiając metody trwałości ubóstwa, dla zachowania czytelności, przyjęto te same założenia jak w analizie przedstawionej w dalszej części pracy, tzn. jednostką badania jest gospodarstwo domowe, miernikiem zamożności - dochody. 
Badanie dynamiki ubóstwa w Polsce z wykorzystaniem modeli analizy historii...

Miernik $P_{\alpha}$, zaproponowany przez Fostera, Greera i Thorbecke, w zależności od przyjętej wartości parametru $\alpha$, można różnie zinterpretować. Przyjmując w formule (1) $\alpha=0$ otrzymujemy:

$$
P_{0}\left(\mathbf{y}, y^{*}\right)=F G T(0)=\frac{1}{n} \sum_{i=1}^{q}\left(\frac{y^{*}-y_{i}}{y^{*}}\right)^{0},
$$

co można zapisać:

$$
P_{0}\left(\mathbf{y}, y^{*}\right)=F G T(0)=H=\frac{q}{n} .
$$

Wskaźnik nazywany jest stopą ubóstwa i najczęściej oznaczany symbolem $H$ (headcount ratio). Jest to miernik szeroko stosowany już od pierwszych badań i pomiarów ilościowych w pracach Bootha i Rowntree. Wskaźnik ten informuje o zasięgu ubóstwa, czyli o udziale ubogich gospodarstw domowych w danej populacji.

Stopa ubóstwa jest miernikiem, którego zasadniczą wadą jest brak informacji o głębokości (natężeniu) ubóstwa. Miernik głębokości ubóstwa otrzymujemy, podstawiając we wzorze (1) $\alpha=1$ :

$$
P_{1}\left(\mathbf{y}, y^{*}\right)=F G T(1)=\frac{1}{n} \sum_{i=1}^{q}\left(\frac{y^{*}-y_{i}}{y^{*}}\right)
$$

Wskaźnik głębokości ubóstwa wskazuje, jaka jest minimalna kwota (w przeliczeniu na osobę, w relacji do granicy ubóstwa), którą każdy musiałby zapłacić, by ubóstwo zostało zlikwidowane. Miernik ten informuje więc o stopniu przeciętnego zubożenia całej populacji.

Głębokość ubóstwa jest również mierzona wskaźnikiem luki dochodowej (luki ubóstwa), który odzwierciedla relatywną (procentową) odległość przeciętnego dochodu biednych gospodarstw domowych od linii ubóstwa. Wskaźnik ten nie należy do klasy miar zaproponowanych przez Fostera, Greera i Thorbecke, a od wskaźnika głębokości ubóstwa $F G T(1)$ różni się tym, że mówi o przeciętnym zubożeniu w grupie biednych, a nie w całej populacji. Formuła pozwalająca wyznaczyć miernik luki dochodowej przyjmuje postać:

$$
P G=\frac{1}{q} \sum_{i=1}^{q}\left(\frac{y^{*}-y_{i}}{y^{*}}\right)=\frac{y^{*}-\bar{y}_{q}}{y^{*}},
$$

gdzie $\bar{y}_{q}-$ średni dochód w grupie ubogich gospodarstw domowych. 
Między wskaźnikiem głębokości ubóstwa $F G T(1)$ a indeksem luki dochodowej $P G$ (poverty gap) zachodzi następująca zależność (Panek 2011: 60):

$$
F G T(1)=H \cdot P G
$$

Indeks luki dochodowej przyjmuje wartość zero, jeżeli w badanej populacji nie ma ubogich gospodarstw domowych, oraz wartość jeden, gdy dochód wszystkich ubogich gospodarstw domowych wynosi zero, czyli występuje „głębokie” ubóstwo. Przykładowo, jeżeli wskaźnik luki dochodowej osiągnie wartość 0,2 oznacza to, że przeciętny dochód grupy gospodarstw ubogich jest o $20 \%$ niższy od granicy ubóstwa.

W pierwszych etapach badań nad ubóstwem, pomiar miał charakter statyczny. Rosnąca dostępność danych longitudinalnych (badania panelowe) w różnych krajach przyczyniła się do rozwoju ujęcia dynamicznego. Początkowo rozważania koncentrowały się na analizie zmian i czasu trwania okresów ubóstwa. Podejścia te podkreślały znaczenie przepływów z i do sfery ubóstwa oraz zróżnicowanie wzorców dynamiki ubóstwa $\mathrm{w}$ różnych populacjach. Jednym z podejść, skupiającym się na zmianie przynależności gospodarstw domowych do sfery ubóstwa, jest wskaźnik mobilności Shorrocksa (1978). Przy konstrukcji indeksu wykorzystywana jest macierz przejścia (transformacji), opisująca mobilność gospodarstw domowych ze względu na ich przynależność do sfery ubóstwa w kolejnych latach badania. W przypadku analizy ubóstwa $\mathrm{w}$ podejściu klasycznym wielkości na przekątnej macierzy wskazują liczby gospodarstw, które nie zmieniły w porównywanych okresach swojego statusu (w obu porównywanych okresach należały lub nie należały do sfery ubóstwa). Poniżej przekątnej znajdują się liczby gospodarstw, które opuściły sferę ubóstwa, a powyżej przekątnej, tych które weszły do sfery ubóstwa (Panek 2007). Indeks mobilności Shorrocksa, stanowiący syntetyczną ocenę skali mobilności gospodarstw domowych ze względu na zagrożenie ubóstwem, przyjmuje postać (Shorrocks 1978, Panek 2007):

$$
M=\frac{n-\operatorname{tr}(\mathbf{N})}{n-1},
$$

gdzie:

$n$ - liczba badanych gospodarstw domowych, $\operatorname{tr}(\mathbf{N})$ - ślad macierzy przejścia, czyli liczba gospodarstw domowych, które nie zmieniły w porównywanych okresach swojego statusu przynależności do sfery ubóstwa $\mathbf{N}=\left[\boldsymbol{n}_{j j^{\prime},(t-1, t)}\right]-$ macierz przejścia, przy czym:

$\boldsymbol{n}_{j j^{\prime},(t-1, t)}$ - liczba gospodarstw domowych, która w okresie $[t-1, t]$ napłynęła z $j-$ tego stanu przynależności do sfery ubóstwa do stanu $j^{\prime}$ 
Badanie dynamiki ubóstwa w Polsce z wykorzystaniem modeli analizy historii...

Wskaźnik mobilności Shorrocksa przyjmuje wartości z przedziału $\left[0, \frac{n}{n-1}\right]$. Im wyższa wartość indeksu, tym większa mobilność gospodarstw domowych (Panek 2007). Rozszerzenie możliwości analitycznych indeksu (7) zaproponował T. Panek (2001) poprzez normalizację indeksu tak, aby przyjmował zawsze wartości z przedziału $[0,1]$ oraz jego dekompozycję:

$$
M=\frac{n-\operatorname{tr}(\mathbf{N})}{n-1}=\frac{\sum_{j>j^{\prime}} n_{j j^{\prime}}+\sum_{j<j^{\prime}} n_{j j^{\prime}}}{n-1}=\frac{\sum_{j>j^{\prime}} n_{j j^{\prime}}}{n-1}+\frac{\sum_{j<j^{\prime}} n_{j j^{\prime}}}{n-1}=M U^{+}+M U^{-} .
$$

Pierwszy z elementów prawej strony równania wskazuje odsetek gospodarstw domowych charakteryzujących się spadkiem stopnia zagrożenia ubóstwem w porównywanych okresach (udział gospodarstw opuszczających sferę ubóstwa). Drugi składnik to odsetek gospodarstw domowych, w których nastąpił wzrost zagrożenia ubóstwem w badanym okresie (udział gospodarstw wchodzących do sfery ubóstwa). Jako uzupełnienie indeksu mobilności T. Panek (2001) zaproponował indeks charakteru mobilności gospodarstw domowych:

$$
C M=\frac{\sum_{j>j^{\prime}} n_{j j^{\prime}}}{n-1}-\frac{\sum_{j<j^{\prime}} n_{j j^{\prime}}}{n-1}=M U^{+}-M U^{-},
$$

Indeks ten przyjmuje wartości z przedziału $[-1,1]$. Wartości dodatnie oznaczają przewagę przepływów gospodarstw domowych z grup o wyższym zagrożeniu ubóstwem do grup o niższym zagrożeniu ubóstwem. Wartości ujemne indeksu wskazują na przewagę przepływów zwiększających zagrożenie ubóstwem nad przepływami zmniejszającymi zagrożenie ubóstwem. Im wyższa wartość bezwzględna indeksu, tym większa przewaga jednego typu przepływów nad drugim.

Wadą omawianego indeksu mobilności Shorrocksa oraz indeksów stanowiących jego modyfikację jest możliwość porównania zmian przynależności do sfery ubóstwa jedynie w dwóch okresach badania. W celu uzyskania pełnego obrazu zmian, jakie zachodziły w okresie np. dziesięciu lat, należy przeanalizować wartości indeksów dla każdego roku.

W ostatnim czasie można zauważyć rosnące zainteresowanie nową metodologią badania trwałości ubóstwa. W konstrukcji spójnego, zagregowanego wskaźnika proponuje się uwzględnić profile grup gospodarstw domowych wyróżnionych ze względu na zmiany poziomu dochodów w czasie (Gradín i in. 2010: 2). W literaturze przedmiotu można spotkać się z dwoma podejściami, mającymi na celu budowę zagregowanego wskaźnika, które w 2000 r. zdefiniował Yaqub (2000: 4). W pierwszym podejściu - spells approach - uwaga jest skupiona na okresie trwa- 
nia ubóstwa i przejściach z i do sfery ubóstwa, gdzie przez „okres ubóstwa” (Bane i Ellwood 1986) należy rozumieć liczbę przedziałów czasowych, podczas których dochód gospodarstwa domowego jest niższy od wyznaczonej granicy ubóstwa. Drugim podejściem, wymienionym przez Yaquba, jest podejście components approach, które skupia się na szacowaniu trwałych i przejściowych składników ubóstwa. Podejście „komponentowe” zakłada wyrównanie pomiędzy okresami niskich i wysokich dochodów (wykorzystanie koncepcji dochodu permanentnego), a wtedy identyfikacja gospodarstw ubogich w każdym przedziale czasowym jest niepotrzebna. Podejście „okresowe” nie zakłada takiego wyrównania i dokonuje identyfikacji gospodarstw ubogich w każdym okresie badania (Gradín i in. 2010: 4). Dwa przedstawione podejścia nie są równoważne: podejście „okresowe” odróżnia gospodarstwa trwale ubogie od reszty gospodarstw domowych, natomiast podejście „komponentowe" pozwala odróżnić trwałe ubóstwo gospodarstw domowych od ich ubóstwa przejściowego (Yaqub 2000: 4). Oba podejścia, „okresowe” i „komponentowe" wykorzystywane są do sumowania wzorców dochodowych wszystkich gospodarstw domowych w zagregowany wskaźnik ubóstwa międzyokresowego (aggregate intertemporal poverty index). Poniżej omówiono budowę zagregowanego wskaźnika na przykładzie podejścia spells approach.

Pierwszym krokiem w podejściu „okresowym” jest obliczenie indywidualnego miernika ubóstwa międzyokresowego, bazującego na wyznaczanych w określonych momentach badania indywidualnych wskaźnikach ubóstwa. W drugim kroku, uśredniając indywidualne wskaźniki, otrzymuje się zagregowany indeks dla całej badanej populacji. Przykłady takiego podejścia w konstruowaniu zagregowanego wskaźnika można znaleźć m.in. w pracach Rainwatera (1981), Duncana, Coe i Hill (1984), Duncana i Rodgersa (1991), Gaiha i Deolalikara (1993), Betti i Vermy (2004). Wskaźnik ubóstwa międzyokresowego (trwałego) przyjmuje wartość jeden, jeśli liczba okresów, w których gospodarstwo domowe znajduje się poniżej wyznaczonej linii ubóstwa, przekracza pewną ustaloną liczbę.

Przykładowo, w pracy Betti i Vermy (2004: 26) zastosowano podział na nieubogich (never poor), dotkniętych ubóstwem (ubogi w dowolnym okresie badania - any-time poor), trwale ubogich (persistently poor) i ciągle ubogich (continuosly poor). W omawianym ujęciu trwałe ubóstwo to ubóstwo występujące przynajmniej w połowie badanych okresów, natomiast ubóstwo ciągłe to ubóstwo występujące we wszystkich okresach. Stosując do podziału zaproponowanego przez Betti i Vermę uwagę Rodgers i Rodgersa (1993), mówiącą o tym, że trwałe ubóstwo to ubóstwo, które występuje we wszystkich lub prawie we wszystkich okresach badania, natomiast ubóstwo przejściowe - tylko w kilku badanych okresach, oraz biorąc pod uwagę zastosowane rozgraniczenie między trwale ubogimi (będący w sferze ubóstwa przynajmniej przez $50 \%$ badanych okresów) i przejściowo ubogimi (znajdujący się w sferze ubóstwa do 50\% okresów w ubóstwie) zawarte w pracy Topińskiej (2005), ostatecznie otrzymujemy następujący podział gospodarstw: 
Badanie dynamiki ubóstwa w Polsce z wykorzystaniem modeli analizy historii...

1. nieubogie $\mathrm{w}$ żadnym $\mathrm{z}$ badanych okresów (never poor), czyli $t=0$, gdzie $t(0 \leq t \leq T)$ oznacza liczbę okresów w ubóstwie, $T$ - liczba badanych okresów.

2. dotknięte ubóstwem (any-time poor), czyli gospodarstwa, które były ubogie przynajmniej w jednym z badanych okresów: $1 \leq t \leq T$,

3. okresowo (przejściowo) ubogie (transitorily poor), czyli gospodarstwa znajdujące się w sferze ubóstwa do 50\% badanych okresów: $1 \leq t \leq \operatorname{int}(T / 2)$, gdzie int( $T$ / 2) oznacza część całkowitą z dzielenia liczby badanych okresów przez dwa.

4. trwale (chronicznie, długookresowo) ubogie (persistently poor) - gospodarstwa, które we wszystkich lub w większości analizowanych okresów są w sferze ubóstwa (ponad 50\% okresów w ubóstwie), co można zapisać w następujący sposób: $\operatorname{int}(T / 2)+1 \leq t \leq T$, gdzie $\operatorname{int}(T / 2)+1$ oznacza najmniejszą liczbę całkowitą ściśle większą od $T$ / 2 .

Przedstawiony powyżej, dosyć intuicyjny, podział gospodarstw w zależności od liczby okresów przebywania w sferze ubóstwa znajduje często zastosowanie w badaniach empirycznych.

\section{DANE I METODA}

Badanie dynamiki ubóstwa w Polsce przeprowadzono na podstawie wyników sześciu etapów panelu zrealizowanych w latach 2000-2011 w ramach projektu Diagnoza społeczna (Rada Monitoringu Społecznego 2012). W kolejnych fazach tego badania uczestniczą wszystkie dostępne gospodarstwa domowe z poprzedniej rundy oraz gospodarstwa z nowej reprezentatywnej próby. Przeprowadzona analiza dynamiki ubóstwa odnosi się tylko do gospodarstw domowych uczestniczących we wszystkich etapach panelu.

W przeprowadzonej analizie ubóstwa przyjęto ekonomiczną definicję ubóstwa ${ }^{3}$, jednostką badania było gospodarstwo domowe. Jako wskaźnik zamożności gospodarstw przyjęto dochód netto gospodarstw domowych w Polsce w lutym 2000, 2003, 2005, 2007, 2009 i 2011 r. Dla zachowania porównywalności sytuacji gospodarstw o różnej wielkości i różnym składzie demograficznym obliczono tzw. dochody ekwiwalentne, stosując zmodyfikowaną skalę ekwiwalentności OECD typu 0,5/0,3, obliczaną w następujący sposób (Szukiełojć-Bieńkuńska 2008: 56): wartość 1 przypisuje się pierwszej osobie dorosłej w gospodarstwie, 0,5 - każdemu następnemu dorosłemu członkowi gospodarstwa, 0,3 - każdemu dziecku poniżej 14 lat. W pracy przyjęto, iż dochody przeliczone na jednostkę ekwiwalentną są ważone liczbą gospodarstw domowych. Na potrzeby analiz przyjęto relatywną linię ubóstwa, obliczaną jako $60 \%$ mediany rozkładu dochodów ekwiwalentnych ${ }^{4}$.

\footnotetext{
3 Patrz (Rusnak 2007: 146).

4 Linia ta jest obiektywną granicą ubóstwa.
} 
Zmienną wynikową, będącą przedmiotem zainteresowania w niniejszym artykule, jest indywidualna zmiana statusu ubóstwa z okresu na okres. Wejście w sferę ubóstwa (poverty entry) jest zmianą ze stanu nieubogi na ubogi, natomiast wyjście ze sfery ubóstwa (poverty exit) jest zmianą o przeciwnym charakterze. $\mathrm{W}$ badanym okresie 2000-2011 jednostki mogą wejść (lub wyjść) do sfery ubóstwa co najwyżej dwukrotnie. Pierwsze wejście (lub wyjście) do sfery ubóstwa nie może być obserwowane przed 2005 r., czyli przed drugim etapem badania. Ponowne wejście (wyjście) do sfery ubóstwa nie może mieć miejsca przed 2009 r. Wejścia i wyjścia ze sfery ubóstwa nazywane są zdarzeniami (events), natomiast okresy pomiędzy dwoma wejściami (lub wyjściami) do sfery ubóstwa to epizody (spells). Epizod można również określić jako czas oczekiwania na wystąpienie zdarzenia (Frątczak i in. 2005: 23). Kluczową kwestią pojawiającą się w analizie czasu trwania (analizie historii zdarzeń) jest wskaźnik hazardu (hazard rate), który jest definiowany jako prawdopodobieństwo doświadczenia zdarzenia (wejście lub wyjście ze sfery ubóstwa), po określonej liczbie lat, w których to zdarzenie nie miało miejsca. Wskaźniki hazardu są więc prawdopodobieństwami warunkowymi, które zależą od tego jak długo trwa epizod, a przy ich liczeniu uwzględniana jest jedynie populacja mogąca doświadczyć zdarzenia (Jenkins i in. 2001). Ponieważ zdarzenie - wejście lub wyjście ze sfery ubóstwa - może nastąpić w dowolnym czasie, a baza projektu Diagnoza społeczna zawiera informacje o dochodach w odstępach dwu- i trzyletnich, stąd model hazardu o czasie dyskretnym (discrete-time hazard model) jest bardziej odpowiedni niż model hazardu o czasie ciągłym (Jenkins 2004). Modele o czasie dyskretnym stosowane $\mathrm{w}$ analizie historii zdarzeń są pewną aproksymacją modeli o czasie ciągłym (Frątczak i in. 2005: 127). Znanym i często używanym modelem o czasie dyskretnym jest model logitowy.

\section{MODELOWANIE HAZARDU O CZASIE DYSKRETNYM - TRANSFORMACJA JEDNOKIERUNKOWA}

Niech próba składa się z $n$ niezależnych jednostek $(i=1,2, \ldots, n)$ z odpowiednimi czasami zdarzeń $T_{i}$ względem znanego czasu rozpoczęcia $t=0$ (Allison 1982, Callens i Croux 2009, Willet i Singer 1995, Yamaguchi 1991: 17-18, 49-53). Zakładamy, że dyskretne zmienne losowe $T_{i}$ są nieujemne, niezależne i podlegają temu samemu rozkładowi. $\mathrm{W}$ pierwszej, przeprowadzonej w niniejszym artykule analizie, w trakcie zdarzenia $T_{i}$ jednostka $i$ przechodzi ze sfery poza ubóstwem do sfery ubóstwa, natomiast $\mathrm{w}$ drugiej analizie zdarzeniem jest przejście ze sfery ubóstwa do sfery poza ubóstwem. Wskaźnik hazardu o czasie dyskretnym $P_{i t}$ jest definiowany jako prawdopodobieństwo warunkowe tego, że jednostka $i$ doświadczy zdarzenia w czasie dyskretnym $t$, przy czym zdarzenie to nie przydarza się jednostce przed czasem $t$ : 
Badanie dynamiki ubóstwa w Polsce z wykorzystaniem modeli analizy historii...

$$
P_{i t}=\operatorname{Pr}\left(T_{i}=t \mid T_{i} \geq t\right) .
$$

W następnym kroku należy określić, w jaki sposób wskaźnik hazardu zależy od czasu i zmiennych objaśniających. W tym celu można wykorzystać funkcję regresji logistycznej:

$$
P_{i t}=\frac{1}{1+\exp \left(-\alpha_{t}-\beta x_{i t}\right)},
$$

którą można zapisać w postaci logitowej:

$$
\log \left(\frac{P_{i t}}{1-P_{i t}}\right)=\alpha_{t}+\beta x_{i t}
$$

Zmienne $x_{i t}$ mogą być zmiennymi o wartościach stałych lub o wartościach zmieniających się w czasie. W modelu tym $\alpha_{t}$ jest pewną funkcją czasu, zwaną logitem funkcji hazardu bazowego (baseline hazard function), która może przybrać postać funkcji liniowej czy kwadratowej. W najbardziej elastycznym modelu, wykorzystywanym często w praktyce, czas jest traktowany jako zmienna zero-jedynkowa z kategorią określoną dla każdego przedziału czasowego:

$$
\alpha_{t}=\alpha_{1 i} D_{1}+\alpha_{2 i} D_{2}+\ldots+\alpha_{s i} D_{s}
$$

gdzie $D_{1}, D_{2}, \ldots, D_{\mathrm{s}}$ są zmiennymi zero-jedynkowymi dla przedziałów czasowych $t=1,2, \ldots, s$, gdzie $s$ jest maksymalnym obserwowanym czasem zdarzenia.

\section{MODELOWANIE HAZARDU O CZASIE DYSKRETNYM - TRANSFORMACJA DWUKIERUNKOWA}

Gospodarstwa domowe uczestniczące w panelu w ramach projektu Diagnoza społeczna mogły wejść do sfery ubóstwa (lub poza ubóstwem) maksymalnie dwukrotnie, co oznacza, że zdarzenia mogły się powtórzyć. Modele logitowe mogą być również określone dla powtarzających się zdarzeń (recurrent events).

Niech $T_{i k}$ będzie zestawem zmiennych losowych oznaczających czas, w którym $k$-te zdarzenie przydarzy się $i$-tej jednostce, oraz niech $t_{i k}$ będzie realizacją zmiennej losowej $T_{i k}$. Początek ryzyka dla zdarzenia $k$ jest definiowany jako pierwszy punkt czasu, w którym miała miejsce zmiana statusu (po wystąpieniu zdarzenia $k-1$ ). 
Wskaźnik hazardu o czasie dyskretnym dla $i$-tej jednostki dla pierwszego zdarzenia $(k=1)$ jest definiowany następująco (Allison 1982, Callens i Croux 2009):

$$
P_{i 1 t}=\operatorname{Pr}\left(T_{i 1}=t \mid T_{i 1} \geq t\right),
$$

natomiast dla kolejnych zdarzeń $k=2,3, \ldots$ ma on postać:

$$
P_{i k t}=\operatorname{Pr}\left(T_{i k}=t \mid T_{i k} \geq t, T_{i 1}=t_{i 1}, T_{i 2}=t_{i 2}, \ldots, T_{i(k-1)}=t_{i(k-1)}\right) .
$$

W następnym kroku należy określić, w jaki sposób wskaźnik hazardu zależy od czasu i zmiennych objaśniających (Steele 2005):

$$
\log \left(\frac{P_{i k t}}{1-P_{i k t}}\right)=\alpha_{t}+\beta x_{i k t}+u_{i},
$$

gdzie:

$t$ - przyjmuje wszystkie możliwe wartości trwania zmiennej dla $k$-tego epizodu, $u_{i}$ - efekt losowy reprezentujący niezaobserwowane charakterystyki $i$-tej jednostki. Jest to „wspólna słabość” (shared frailty) - jest ona wspólna dla wszystkich epizodów. Przyjmijmy, że $u_{i} \sim N\left(0, \sigma_{u}^{2}\right)$.

$\mathrm{W}$ terminologii modelowania wielopoziomowego model (16) jest (Steele 2011) dwupoziomowym modelem z losowym wyrazem wolnym (two-level random intercept model). W modelu tym logarytm ilorazu szans (log-odds) zdarzenia w przedziale czasu $t$ jest zwiększany lub zmniejszany o wartość $u_{i}$ dla $i$-tej jednostki, przy czym wartość $u_{i}$ jest stała dla $i$-tej jednostki.

Modele logitowe dla powtarzających się zdarzeń można dopasowywać, stosując procedury dla wielopoziomowych danych binarnych, dostępne w wielu pakietach statystycznych. Należy jednak zaznaczyć, że pakiety różnią się wykorzystywanymi procedurami estymacji, co prowadzi do różnic w uzyskiwanych ocenach parametrów. Parametry modeli mogą być szacowane metodą największej wiarygodności za pomocą kwadratury numerycznej (np. SAS, Stata, SABRE), metodami quasi-największej wiarygodności (HLM i MLwiN) i metodami Monte Carlo opartymi na łańcuchach Markowa (WinBUGS i MLwiN). Wielu autorów podkreśla (np. Browne i in. 2001), że metody Monte Carlo oparte na łańcuchach Markowa (Markov Chain Monte Carlo - MCMC) są metodami najbardziej elastycznymi i mogą być używane do estymacji skrajnie złożonych modeli wielopoziomowych dla struktur hierarchicznych i niehierarchicznych. 
Badanie dynamiki ubóstwa w Polsce z wykorzystaniem modeli analizy historii...

\section{KONSTRUKCJA DANYCH WEJŚCIOWYCH}

Dane o historii zdarzeń są często przedstawiane w formie jeden rekord na jednostkę. Szacowanie modeli wymaga jednak przekształcenia (Steele 2011) tych danych do pliku postaci osoba-epizod (person-episode-based file), czyli do pliku z danymi o każdym z epizodów dla $i$-tej osoby. Przed wykonaniem analizy plik osoba-epizod musi zostać rozszerzony do pliku osoba-epizod-okres (person-episode-period file), zawierającego dane o trwaniu $k$-tego epizodu $i$-tej jednostki rozszerzonego do rekordów $t_{i k}$, gdzie $t_{i k}$ oznacza liczbę okresów, w których jednostka $i$ jest obserwowana $\mathrm{w}$ stanie epizodu $k$. Dla każdego rekordu $\mathrm{t}=1, \ldots, t_{i k}$ można zdefiniować wskaźnik zero-jedynkowy:

$$
y_{i k t}= \begin{cases}1 & \text { jeśli } k \text {-ty epizod } i \text {-tej jednostki kończy się w przedziale } t \\ 0 & \text { w przeciwnym razie }\end{cases}
$$

Wszystkie epizody, niezależnie od tego, czy ich trwanie jest ocenzurowane, przyjmą $y_{i k t}=0$ dla przedziałów $t=1, \ldots, t_{i k}-1$. Odpowiedź w ostatnim obserwowanym przedziale przyjmie wartość równą 1 dla epizodów, które kończą się zdarzeniem w trakcie tego okresu, a wartość 0 dla danych ocenzurowanych w przedziale $t_{i k}$.

\section{CENZUROWANIE INFORMACJI}

Analizując trwanie ubóstwa, wielokrotnie zdarzają się sytuacje, w których historia epizodu nie jest kompletna - pojawia się problem cenzurowania prawo- i lewostronnego. Oznacza to, że pewne epizody zaczynają się i kończą poza okresem badania. Informacji ocenzurowanych lewostronnie nie uwzględniono w analizie - wzięto pod uwagę te epizody, które rozpoczęły się w trakcie badanego okresu. Przykładowo, analizując wyjścia ze sfery ubóstwa, wymagamy, aby jednostka była nieuboga w pierwszym okresie, uboga w drugim okresie i dopiero od trzeciego okresu można zaobserwować, czy jednostka opuściła sferę ubóstwa. Odpowiednio przyjmujemy, że wejścia do sfery ubóstwa są praktycznie ponownymi wejściami do sfery ubóstwa, ponieważ wymagamy, aby jednostka była uboga w pierwszym okresie, opuściła sferę ubóstwa w drugim okresie i dopiero od trzeciego okresu można obserwować, czy jednostka weszła ponownie do sfery ubóstwa i kiedy.

Z cenzurowaniem prawostronnym mamy do czynienia, gdy epizod nie kończy się w trakcie okresu obserwacji. Wyłączanie obserwacji prawostronnie ocenzurowanych prowadzi do obciążenia i może znacząco zredukować rozmiar próby. W analizie historii zdarzeń obserwacje te są uwzględniane w obliczeniach i zazwyczaj zakłada się, że cenzurowanie jest losowe, tzn. czasy zdarzeń są niezależne od mechanizmu cenzurowania (Steele 2007). 


\section{WSKAŹNIKI WEJŚĆ I WYJŚĆ ZE SFERY UBÓSTWA W ŚWIETLE BADAŃ PANELOWYCH}

Zmiany w sferze ubóstwa są najczęściej określane na podstawie stóp ubóstwa liczonych odrębnie dla każdego badanego okresu. Analizy te są coraz częściej poszerzane o kategorie dynamiczne, dzięki czemu istnieje możliwość wskazania grup szczególnie zagrożonych ubóstwem trwałym, a co za tym idzie, grup, które potrzebują największej pomocy ze strony państwa. Ocena trwałości ubóstwa z zastosowaniem kategorii dynamicznych nie pozwala jednak udzielić odpowiedzi na pytanie, czy zmiany w sferze ubóstwa, które nastąpiły w latach poprzednich, mają wpływ na teraźniejszą sytuację materialną. Wymaga to określenia warunkowych prawdopodobieństw, które pozwolą określić wpływ czasu spędzonego poza sferą ubóstwa na wejście do sfery ubóstwa oraz wpływ czasu spędzonego w sferze ubóstwa na wyjście z tej sfery. W przeprowadzonej analizie wyłączono informacje ocenzurowane lewostronnie - dwa pierwsze etapy badania (lub więcej) zostały użyte do określenia warunku, czy gospodarstwo jest „,na wejściu” ubogie czy nieubogie. W konsekwencji, jedynie maksymalnie cztery fale badania są wykorzystywane do określenia wejść i wyjść ze sfery ubóstwa.

Przed oszacowaniem modeli logitowych, pozwalających określić warunkowe prawdopodobieństwa, przeprowadzono analizę wskaźników wejść i wyjść ze sfery ubóstwa. W tablicy 1 przedstawiono obliczone wartości wskaźników hazardu wejść i wyjść ze sfery ubóstwa oraz skumulowanych odsetków gospodarstw domowych pozostających poza sferą ubóstwa oraz pozostających w sferze ubóstwa (wskaźniki przeżyć).

Wskaźnik hazardu informuje o udziale, w każdym z okresów ${ }^{5}$, gospodarstw domowych, które wchodzą (lub wychodzą) do sfery ubóstwa w ogóle gospodarstw domowych narażonych na ryzyko zajścia zdarzenia (odpowiednio wejścia lub wyjścia ze sfery ubóstwa) w danym okresie. Większe ryzyko hazardu oznacza większe ryzyko wejścia (lub wyjścia) do sfery ubóstwa. Na przykład, w przypadku wejść do sfery ubóstwa, wskaźnik hazardu równy $6,8 \%$ oznacza, że $6,8 \%$ gospodarstw domowych będących poza sferą ubóstwa na początku drugiego okresu, opuściło tę sferę $\mathrm{w}$ trakcie drugiego okresu.

Obliczony wskaźnik przeżycia dla okresu $t$ informuje o skumulowanym udziale gospodarstw domowych, które nie doświadczyły zdarzenia przed okresem $t$. Oszacowanie wskaźnika dla okresu $t$ sprowadza się do obliczenia iloczynu odsetków gospodarstw niedoświadczających zdarzenia w poprzednich okresach. Przykładowo, w przypadku wejść do sfery ubóstwa, obliczony dla ostatniego okresu wskaźnik przeżycia oznacza, że 79,8\% gospodarstw było poza sferą ubóstwa na początku czwartego okresu.

5 Pojęcie „okres” będzie od tego momentu używane zamiast „przedział czasu” i będzie się odnosić do dwuletnich przerw pomiędzy etapami panelu. 
Badanie dynamiki ubóstwa w Polsce z wykorzystaniem modeli analizy historii...

Tablica 1. Wejścia i wyjścia ze sfery ubóstwa - wskaźniki hazardu i przeżyć

Table 1. Entries into and exits from poverty - hazard and survival indices

\begin{tabular}{|c|c|c|c|c|}
\hline \multirow{2}{*}{$\begin{array}{c}\text { Przedział czasu } t \\
\text { Time interval } t\end{array}$} & \multicolumn{2}{|c|}{ Wejścia } & \multicolumn{2}{c|}{ Wyjścia } \\
\cline { 2 - 5 } & $\begin{array}{c}\text { Extries } \\
\text { hazkaźnik } \\
\text { hazard index }\end{array}$ & $\begin{array}{c}\text { wskaźnik } \\
\text { przeżycia } \\
\text { survival index }\end{array}$ & $\begin{array}{c}\text { wskaźnik } \\
\text { hazardu } \\
\text { hazard index }\end{array}$ & $\begin{array}{c}\text { wskaźnik } \\
\text { przeżycia } \\
\text { survival index }\end{array}$ \\
\hline 1 & 0,092 & 1,000 & 0,274 & 1,000 \\
\hline 2 & 0,068 & 0,908 & 0,219 & 0,726 \\
\hline 3 & 0,057 & 0,846 & 0,301 & 0,567 \\
\hline 4 & 0,041 & 0,798 & 0,222 & 0,396 \\
\hline
\end{tabular}

Źródło: Obliczenia własne na podstawie Rada Monitoringu Społecznego (2012).

Source: Own calculations based on Social Monitoring Council (2012).

\section{ANALIZA HAZARDU WEJŚĆ I WYJŚĆ ZE SFERY UBÓSTWA}

Modele logitowe wejść i wyjść ze sfery ubóstwa szacowano w dwóch wariantach. W pierwszym wariancie (model 1) uwzględniono jedynie zmienne zero-jedynkowe reprezentujące liczbę okresów spędzonych poza sferą ubóstwa (analiza wejść) lub liczbę lat spędzonych w sferze ubóstwa (analiza wyjść). Modele te pozwoliły określić prawdopodobieństwo wejścia (lub wyjścia) do sfery ubóstwa w okresie $t$ po $t$-1 okresach spędzonych poza sferą ubóstwa (lub w sferze ubóstwa). W drugim wariancie (model 2) do modelu bazowego dodano zmienne charakteryzujące zarówno głowę gospodarstwa domowego, jak i samo gospodarstwo: płeć, wiek oraz wykształcenie głowy gospodarstwa oraz miejsce zamieszkania i status gospodarstwa na rynku pracy.

Modele logitowe zostały oszacowane w programie MLwiN. Do estymacji modeli wykorzystano metody bayesowskie, które umożliwiają uwzględnienie w badaniu wcześniej zdobytej wiedzy spoza próby. Łączenie dodatkowej wiedzy a priori $\mathrm{z}$ informacją pochodzącą z obserwowalnych danych, za pomocą twierdzenia Bayesa, stanowi podstawę metod bayesowkich. Twierdzenie Bayesa przekształca posiadaną wiedzę przed obserwacją oraz nową informację zawartą w empirycznych danych w prawdopodobieństwo a posteriori. Wnioskowanie w statystyce bayesowkiej bazuje na tak otrzymanych rozkładach a posteriori. Analityczne wyznaczanie rozkładów a posteriori jest dość trudne i często wymaga wykorzystania metod symulacyjnych, do których zaliczane są metody MCMC (Grzenda 2012).

Do estymacji modeli logitowych wejść i wyjść ze sfery ubóstwa wykorzystano metody MCMC, stosując algorytm Metropolisa-Hastingsa. W przeprowadzonej analizie użyto następujących rozkładów a priori: 
- dla współczynników regresji $\beta$ - rozkład jednostajny a priori. Łączna gęstość a priori jest następująca: $p(\beta) \propto 1$.

- dla wariancji: $p\left(\frac{1}{\sigma^{2}}\right) \sim \Gamma(\varepsilon, \varepsilon)$, gdzie $\varepsilon$ jest bardzo mały (przyjęto $\varepsilon=0,001$ ).

Procedurę MCMC rozpoczęto od ustalenia wartości początkowych dla pierwszego łańcucha Markowa. Wartości inicjujące stanowiły wartości parametrów estymowanych jedną z metod quasi-największej wiarygodności - metodą PQL drugiego stopnia ( $2^{\text {nd }}$ order penalized quasi-likelihood). W modelowaniu wielopoziomowym jest bowiem naturalne przyjęcie jako wartości początkowych rezultatów estymacji metodą największej wiarygodności lub metodą quasi-największej wiarygodności: MQL (marginal quasi-likelihood) lub PQL (Browne 2006).

Oceny dopasowania oszacowanych modeli dokonano za pomocą miary DIC (Deviance Information Criterion), będącej uogólnieniem kryterium informacyjnego Akaikego. Modele z niższymi wartościami DIC powinny być preferowane nad modelami z wyższymi wartościami.

W pierwszej kolejności dokonano analizy hazardu wejść do sfery ubóstwa, uwzględniając w modelu 1 liczbę okresów spędzonych poza sferą ubóstwa (tablica 2).

W modelu tym hazard wejścia do sfery ubóstwa maleje wraz ze wzrostem czasu spędzonego poza sferą ubóstwa, co znajduje odzwierciedlenie prawdopodobieństwach obliczonych na podstawie oszacowanego modelu. Przewidywane prawdopodobieństwo wejścia do sfery ubóstwa jest więc największe po jednym okresie spędzonym poza sferą ubóstwa $(0,094)$, natomiast najmniejsze - po czterech okresach $(0,042)$. Należy jednocześnie zauważyć, że zmienne określające czas trwania poza sferą ubóstwa są, poza jednym wyjątkiem, statystycznie nieistotne na poziomie 0,05 . Również wariancja dla losowego wyrazu wolnego na poziomie gospodarstw domowych jest nieistotna statystycznie, co oznacza, że nie ma zróżnicowania pomiędzy gospodarstwami. 
Badanie dynamiki ubóstwa w Polsce z wykorzystaniem modeli analizy historii...

Tablica 2. Analiza hazardu wejść do sfery ubóstwa: wyniki estymacji modelu 1 (hazard bazowy) Table 2. Hazard analysis of entries into poverty: estimation results of model 1 (baseline hazard)

\begin{tabular}{|c|c|c|c|}
\hline Zmienna & $\begin{array}{c}\text { Współczynnik } \\
\text { Coefficient }\end{array}$ & $\begin{array}{c}\text { Błąd } \\
\text { standardowy } \\
\text { Standard error }\end{array}$ & Variable \\
\hline $\begin{array}{l}\text { Wejście do sfery ubóstwa: } \\
\text { po } 1 \text { okresie poza sferą ubóstwa } \\
\text { po } 2 \text { okresach poza sferą ubóstwa } \\
\text { po } 3 \text { okresach poza sferą ubóstwa } \\
\text { po } 4 \text { okresach poza sferą ubóstwa } \\
\text { Wyraz wolny } \\
\text { Wariancja wyrazu wolnego }\end{array}$ & $\begin{array}{c}\text { ref. } \\
-0,364 \\
-0,542 \\
-0,909^{*} \\
-2,318^{*} \\
0,068\end{array}$ & $\begin{array}{l}0,282 \\
0,302 \\
0,379 \\
0,184 \\
0,090\end{array}$ & $\begin{array}{l}\text { Poverty entry: } \\
\text { after } 1 \text { period out of poverty } \\
\text { after } 2 \text { periods out of poverty } \\
\text { after } 3 \text { periods out of poverty } \\
\text { after } 4 \text { periods out of poverty } \\
\text { Intercept } \\
\text { Intercept variance }\end{array}$ \\
\hline DIC & \multicolumn{2}{|c|}{667,44} & DIC \\
\hline $\begin{array}{l}\text { Przewidywane } \\
\text { prawdopodobieństwa wejścia do } \\
\text { sfery ubóstwa: } \\
\text { po } 1 \text { okresie poza sferą ubóstwa } \\
\text { po } 2 \text { okresach poza sferą ubóstwa } \\
\text { po } 3 \text { okresach poza sferą ubóstwa } \\
\text { po } 4 \text { okresach poza sferą ubóstwa }\end{array}$ & \multicolumn{2}{|c|}{$\begin{array}{l}0,094 \\
0,068 \\
0,058 \\
0,042\end{array}$} & $\begin{array}{l}\text { Predicted probabilities of } \\
\text { poverty entry: } \\
\text { after } 1 \text { period out of poverty } \\
\text { after } 2 \text { periods out of poverty } \\
\text { after } 3 \text { periods out of poverty } \\
\text { after } 4 \text { periods out of poverty }\end{array}$ \\
\hline
\end{tabular}

* istotność na poziomie 0,05

* significance level 0,05

Źródło: Obliczenia własne na podstawie Rada Monitoringu Społecznego (2012).

Source: Own calculations based on Social Monitoring Council (2012).

Analizując model 2 (tablicy 3) można zauważyć, że cztery zmienne są statystycznie istotne: wiek i wykształcenie głowy gospodarstwa domowego, status gospodarstwa na rynku pracy oraz miejsce zamieszkania. Gospodarstwa domowe mieszkające w miastach oraz gospodarstwa, których głowa ma wykształcenie średnie lub powyżej mają mniejsze szanse na wejście do sfery ubóstwa. Prawdopodobieństwo wejścia do sfery ubóstwa jest natomiast większe w przypadku gospodarstw, w których przynajmniej jedna osoba jest bezrobotna oraz gospodarstw, których głowa ma poniżej 60 lat. 
Tablica 3. Analiza hazardu wejść do sfery ubóstwa: wyniki estymacji modelu 2 (hazard bazowy i zmienne objaśniające)

Table 3. Hazard analysis of entries into poverty: estimation results of model 2 (baseline hazard and explanatory variables)

\begin{tabular}{|c|c|c|c|}
\hline Zmienna & $\begin{array}{c}\text { Współczynnik } \\
\text { Coefficient }\end{array}$ & $\begin{array}{c}\text { Błąd } \\
\text { standardowy } \\
\text { Standard error }\end{array}$ & Variable \\
\hline $\begin{array}{l}\text { Wejście do sfery ubóstwa: } \\
\text { po } 1 \text { okresie poza sferą ubóstwa } \\
\text { po } 2 \text { okresach poza sferą ubóstwa } \\
\text { po } 3 \text { okresach poza sferą ubóstwa } \\
\text { po } 4 \text { okresach poza sferą ubóstwa } \\
\text { Płeć głowy gospodarstwa } \\
\text { domowego: } \\
\text { mężczyzna } \\
\text { kobieta } \\
\text { Wiek głowy gospodarstwa } \\
\text { domowego: } \\
\text { poniżej } 60 \text { lat } \\
60 \text { lat i więcej } \\
\text { Wykształcenie głowy } \\
\text { gospodarstwa domowego: } \\
\text { poniżej średniego } \\
\text { średnie i powyżej } \\
\text { Miejsce zamieszkania: } \\
\text { miasto } \\
\text { wieś } \\
\text { Status gospodarstwa na rynku } \\
\text { pracy: } \\
\text { przynajmniej jedna osoba } \\
\text { bezrobotna } \\
\text { brak osób bezrobotnych } \\
\text { Wyraz wolny } \\
\text { Wariancja wyrazu wolnego }\end{array}$ & $\begin{array}{l}0,531^{*} \\
\text { ref. } \\
\\
\text { ref. } \\
-1,257^{*} \\
-0,777^{*} \\
\text { ref. }\end{array}$ & $\begin{array}{l}0,287 \\
0,308 \\
0,367\end{array}$ & $\begin{array}{l}\text { Poverty entry: } \\
\text { after } 1 \text { period out of poverty } \\
\text { after } 2 \text { periods out of poverty } \\
\text { after } 3 \text { periods out of poverty } \\
\text { after } 4 \text { periods out of poverty } \\
\text { Sex of household head: } \\
\text { male } \\
\text { female } \\
\text { Age of household head: } \\
\text { below } 60 \\
60 \text { and more } \\
\text { Education of household head: } \\
\text { below secondary level } \\
\text { secondary level and more } \\
\text { Place of residence: } \\
\text { urban areas } \\
\text { rural areas } \\
\text { Labour force status of } \\
\text { household: } \\
\text { at least one unemployed } \\
\text { person } \\
\text { without unemployed person } \\
\text { Intercept } \\
\text { Intercept variance }\end{array}$ \\
\hline DIC & \multicolumn{2}{|c|}{606,22} & DIC \\
\hline
\end{tabular}

* istotność na poziomie 0,05 .

* significance level 0,05

Źródło: Obliczenia własne na podstawie Rada Monitoringu Społecznego (2012).

Source: Own calculations based on Social Monitoring Council (2012). 
Badanie dynamiki ubóstwa w Polsce z wykorzystaniem modeli analizy historii...

Obliczone dla modeli 1 i 2 wartości miar DIC pozwalają stwierdzić, iż model 2 mający mniejszą wartość DIC, jest lepiej dopasowany do danych empirycznych.

Wyniki analizy hazardu wyjść ze sfery ubóstwa z uwzględnieniem czasu oczekiwania na wyjście ze sfery ubóstwa (hazard bazowy) przedstawia tabela 4, natomiast z dodatkowymi zmiennymi poza czasem - tablica 5.

Tablica 4. Analiza hazardu wyjść ze sfery ubóstwa: wyniki estymacji modelu 1 (hazard bazowy) Table 4. Hazard analysis of exits from poverty: estimation results of model 1 (baseline hazard)

\begin{tabular}{|c|c|c|c|}
\hline Zmienna & $\begin{array}{c}\text { Współczynnik } \\
\text { Coefficient }\end{array}$ & $\begin{array}{l}\text { Błąd standardowy } \\
\text { Standard error }\end{array}$ & Variable \\
\hline $\begin{array}{l}\text { Wyjście ze sfery ubóstwa: } \\
\text { po } 1 \text { okresie ubóstwa } \\
\text { po } 2 \text { okresach ubóstwa } \\
\text { po } 3 \text { okresach ubóstwa } \\
\text { po } 4 \text { okresach ubóstwa } \\
\text { Wyraz wolny } \\
\text { Wariancja wyrazu wolnego }\end{array}$ & $\begin{array}{c}\text { ref. } \\
-0,281 \\
0,156 \\
-0,338 \\
-1,008^{*} \\
0,011\end{array}$ & $\begin{array}{l}0,282 \\
0,303 \\
0,633 \\
0,165 \\
0,014\end{array}$ & $\begin{array}{l}\text { Poverty exit: } \\
\text { after } 1 \text { period in poverty } \\
\text { after } 2 \text { periods in poverty } \\
\text { after } 3 \text { periods in poverty } \\
\text { after } 4 \text { periods in poverty } \\
\text { Intercept } \\
\text { Intercept variance }\end{array}$ \\
\hline DIC & \multicolumn{2}{|c|}{447,36} & DIC \\
\hline $\begin{array}{l}\text { Przewidywane } \\
\text { prawdopodobieństwa } \\
\text { wyjścia ze sfery ubóstwa: } \\
\text { po } 1 \text { okresie ubóstwa } \\
\text { po } 2 \text { okresach ubóstwa } \\
\text { po } 3 \text { okresach ubóstwa } \\
\text { po } 4 \text { okresach ubóstwa }\end{array}$ & & & $\begin{array}{l}\text { Predicted probabilities of } \\
\text { poverty exit: } \\
\text { after } 1 \text { period in poverty } \\
\text { after } 2 \text { periods in poverty } \\
\text { after } 3 \text { periods in poverty } \\
\text { after } 4 \text { periods in poverty }\end{array}$ \\
\hline
\end{tabular}

* istotność na poziomie 0,05

* significance level 0,05

Źródło: Obliczenia własne na podstawie Rada Monitoringu Społecznego (2012).

Source: Own calculations based on Social Monitoring Council (2012).

W obydwu oszacowanych modelach żadna ze zmiennych nie okazała się statystycznie istotna. W rozważanych modelach można zauważyć, że wyjście ze sfery ubóstwa po dwóch oraz po czterech okresach spędzonych w ubóstwie jest mniej prawdopodobne niż po jednym okresie w sferze ubóstwa. Wyjście po trzecim okresie ubóstwa jest natomiast bardziej prawdopodobne niż po jednym okresie ubóstwa. Spośród tych dwóch modeli, w których wszystkie zmienne okazały się statystycznie nieistotne, modelem preferowanym (na podstawie obliczonych miar DIC) jest model 1 . 
Tablica 5. Analiza hazardu wyjść ze sfery ubóstwa: wyniki estymacji modelu 2 (hazard bazowy i zmienne objaśniające)

Table 5. Hazard analysis of exits from poverty: estimation results of model 2 (baseline hazard and explanatory variables)

\begin{tabular}{|c|c|c|c|}
\hline Zmienna & $\begin{array}{c}\text { Współczynnik } \\
\text { Coefficient }\end{array}$ & $\begin{array}{c}\text { Błąd } \\
\text { standardowy } \\
\text { Standard } \\
\text { error }\end{array}$ & Variable \\
\hline $\begin{array}{l}\text { Wyjście ze sfery ubóstwa: } \\
\text { po } 1 \text { okresie ubóstwa } \\
\text { po } 2 \text { okresach ubóstwa } \\
\text { po } 3 \text { okresach ubóstwa } \\
\text { po } 4 \text { okresach ubóstwa } \\
\text { Płeć głowy gospodarstwa } \\
\text { domowego: } \\
\text { mężczyzna } \\
\text { kobieta } \\
\text { Wiek głowy gospodarstwa } \\
\text { domowego: } \\
\text { poniżej } 60 \text { lat } \\
60 \text { lat i więcej } \\
\text { Wykształcenie głowy gospodarstwa } \\
\text { domowego: } \\
\text { poniżej średniego } \\
\text { średnie i powyżej } \\
\text { Miejsce zamieszkania: } \\
\text { miasto } \\
\text { wieś } \\
\text { Status gospodarstwa na rynku } \\
\text { pracy: } \\
\text { przynajmniej jedna osoba bezrobotna } \\
\text { brak osób bezrobotnych } \\
\text { Wyraz wolny } \\
\text { Wariancja wyrazu wolnego }\end{array}$ & $\begin{array}{c}0,519 \\
\text { ref. } \\
\\
\text { ref. } \\
0,173 \\
-0,017 \\
\text { ref. }\end{array}$ & $\begin{array}{l}0,255 \\
0,293 \\
0,000\end{array}$ & $\begin{array}{l}\text { Poverty exit: } \\
\text { after } 1 \text { period in poverty } \\
\text { after } 2 \text { periods in poverty } \\
\text { after } 3 \text { periods in poverty } \\
\text { after } 4 \text { periods in poverty } \\
\text { Sex of household head: } \\
\text { male } \\
\text { female } \\
\text { Age of household head: } \\
\text { below } 60 \\
60 \text { and more } \\
\text { Education of household head: } \\
\text { below secondary level } \\
\text { secondary level and more } \\
\text { Place of residence: } \\
\text { urban areas } \\
\text { rural areas } \\
\text { Labour force status of } \\
\text { household: } \\
\text { at least one unemployed person } \\
\text { without unemployed person } \\
\text { Intercept } \\
\text { Intercept variance }\end{array}$ \\
\hline DIC & \multicolumn{2}{|c|}{453,95} & DIC \\
\hline
\end{tabular}

* istotność na poziomie 0,05 .

* significance level 0,05

Źródło: Obliczenia własne na podstawie Rada Monitoringu Społecznego (2012).

Source: Own calculations based on Social Monitoring Council (2012).

\section{PODSUMOWANIE}

Celem niniejszego opracowania było określenie wpływu czynnika czasu oraz innych zmiennych na prawdopodobieństwa wejścia i wyjścia ze sfery ubóstwa. W oszacowanych modelach liczba okresów spędzonych poza ubóstwem (w ubó- 
Badanie dynamiki ubóstwa w Polsce z wykorzystaniem modeli analizy historii...

stwie) nie wpływa - poza jednym wyjątkiem - w istotny sposób na prawdopodobieństwo wejścia do sfery ubóstwa (wyjścia ze sfery ubóstwa). Należy jednak zauważyć, że prawdopodobieństwa wejść i wyjść ze sfery ubóstwa, obliczone na podstawie modeli, są równe wskaźnikom hazardu obliczonym bezpośrednio z próby.

Uwzględnienie w modelach innych zmiennych niż czas pozwoliło w przypadku wejść do sfery ubóstwa oszacować lepszy model niż bazowy (mniejsza wartość DIC) i stwierdzić, że na zmianę prawdopodobieństwa wejścia do sfery ubóstwa wpływają istotnie: wiek i wykształcenie głowy gospodarstwa domowego oraz miejsce zamieszkania i status gospodarstwa na rynku pracy. Poszerzony model wyjść ze sfery ubóstwa okazał się modelem gorszym niż bazowy, a żadna ze zmiennych w nim uwzględnionych nie okazała się istotna statystycznie.

Dokonując podsumowania, należy zwrócić uwagę na bardzo istotną kwestię dotyczącą danych, na bazie których przeprowadzono badanie dynamiki ubóstwa. W poszczególnych momentach badania gospodarstwa domowe były uznawane za ubogie (bądź nieubogie) i przyjmowano przy tym założenie, że przebywanie w sferze ubóstwa (lub w sferze poza ubóstwem) trwało do następnego etapu badania. W rzeczywistości czas trwania w ubóstwie (lub poza ubóstwem) mógł być przerywany okresami, w których gospodarstwo domowe było poza sferą ubóstwa (lub odpowiednio w sferze ubóstwa). Innymi słowy, trwanie w ubóstwie (lub poza ubóstwem) mogło być nieciągłe. Przeprowadzone badania nie uwzględniają takiej sytuacji, co niewątpliwie jest ich wadą. Badania panelowe przeprowadzane z odpowiednią częstotliwością pozwoliłyby uniknąć tego niedociągnięcia i tym samym przedstawić pełny obraz zmian przynależności do sfery ubóstwa i sfery poza ubóstwem.

\section{LITERATURA}

Aaberge R., Mogstad M., 2007, On the definition and measurement of chronic poverty, Discussion Paper Series, IZA DP no. 2659.

Abel-Smith B., Townsend P., 1965, The poor and the poorest, Occasional Papers on Social Administration, no. 17 , Bell, London.

Allison P.D., 1982, Discrete-time methods for the analysis of event histories, „Sociological Methodology” vol. 13 , s. 61-98.

Atkinson T., Cantillon B., Marlier E., Nolan B., 2002, Social indicators. The EU and social inclusion, Oxford University Press, New York.

Bane M.J., Ellwood D.T, 1986, Slipping into and out of poverty: the dynamics of spells, "The Journal of Human Resources", vol. 21, s. 1-23.

Betti G., Verma V., 2004, A methodology for the study of multi-dimensional and longitudinal aspects of poverty and deprivation, invited paper, IAOS-IASS Joint Conference, November29-December $1^{\text {st }}, 2004$, Amman-Jordan.

Browne W.J., 2006, A comparison of Bayesian and likelihood-based methods for fitting multilevel models, "Bayesian Analysis", vol. 1, s. 473-514.

Browne W.J., Goldstein H., Rasbash J., 2001, Multiple membership multiple classification (MMMC) models, Statistical Modelling, vol. 1, s. 103-124. 
Callens M., Croux C., 2009, Poverty dynamics in Europe. A multilevel discrete-time recurrent hazard analysis, "International Sociology", vol. 24, s. 368-396.

Diagnoza społeczna 2005. Warunki i jakość życia Polaków, 2006, J. Czapiński, T. Panek (red.), Vizja Press \& IT, Warszawa.

Diagnoza społeczna 2007. Warunki i jakość życia Polaków, 2007, J. Czapiński, T. Panek (red.), Vizja Press \& IT, Warszawa.

Diagnoza społeczna 2009. Warunki i jakość życia Polaków, 2009, J. Czapiński, T. Panek (red.), Centrum Rozwoju Zasobów Ludzkich, Warszawa.

Diagnoza społeczna 2011. Warunki i jakość życia Polaków, 2012, J. Czapiński, T. Panek (red.), Centrum Rozwoju Zasobów Ludzkich, Warszawa.

Duncan G.J., Coe R.B., Hill M.S., 1984, The dynamics of poverty, [w:] G. Duncan (red.), Years of poverty and plenty (s. 33-70), Institute for Social Research, University of Michigan, Ann Arbor MI.

Duncan G.J., Rodgers W., 1991, Has children's poverty become more persistent?, "American Sociological Review", vol. 56, s. 538-550.

Foster J.E., 2007, A class of chronic poverty measures, Working Paper no. 07-W01, Department of Economics, Vanderbilt University.

Foster J., Greer J., Thorbecke E., 1984, A class of decomposable poverty measures, "Econometrica", vol. 52, s. 761-766.

Frątczak E., Gach-Ciepiela U., Babiker H., 2005, Analiza historii zdarzeń. Elementy teorii, wybrane przyktady zastosowań, SGH, Warszawa.

Gaiha R., Deolalikar A.B., 1993, Persistence, expected and innate poverty: estimates for semi arid rural South India, "Cambridge Journal of Economics", vol. 17, s. 409-421.

Goedhart T, Halberstadt V., Kapteyn A., van Praag B., 1977, The poverty line: concept and measurement, "The Journal of Human Resources", vol. 12, s. 503-520.

Gradín C., del Río C., Cantó O., 2010, Measuring poverty accounting for time, Working Papers 169, ECINEQ, Society for the Study of Economic Inequality.

Grzenda W., 2012, Wybrane zagadnienia estymacji bayesowskiej, [w:] E. Frątczak (red.), Zaawansowane metody analiz statystycznych (s. 419-501), SGH, Warszawa.

Hagenaars A.J.M., van Praag B.M.S., 1985, A synthesis of poverty line definitions, "Journal of the International Association for Research in Income and Wealth", Series 31, s. 139-154.

Hagenaars A., de Vos K., 1988, The definition and measurement of poverty, "The Journal of Human Resources", vol. 23, s. 211-221.

Heckman J.J, 1981, Heterogeneity and state dependence, [w:] S. Rosen (red.), Studies in labor markets (s. 91-140), Chicago Press, Chicago, Illinois.

Hulme D., Shepherd A., 2003, Conceptualizing chronic poverty, "World Development", vol. 31, s. 403-423.

Jalan J., Ravallion M., 1998, Determinants of transient and chronic poverty. Evidence from rural China, "Policy Research Working Paper", 1936, The World Bank, Research Development Group, Washington DC.

Jenkins S.P, 2004, Survival analysis (lecture notes), Institute for Social and Economic Research, Univerity of Essex.

Jenkins S.P., Rigg J.A., Devicienti F., 2001, The dynamics of poverty in Britain, Research report no. 157, Corporate Document Services for the Department for Work and Pensions, Great Britain Department for Work and Pensions, Univeristy of Essex, Institute for Social and Economic Research.

Morecka Z., Styrc M., 2008, Przegląd $i$ analiza wyników badań nad przyczynami, zakresem, korelatami i konsekwencjami ubóstwa w Polsce, [w:] S. Golinowska, Z. Morecka, M. Styrc, E. Cukrowska, J. Cukrowski, Od ubóstwa do wykluczenia społecznego. Badania. Koncepcje. Wyniki. Propozycje Polska, Europa i świat (s. 9-71), IPiSS, Warszawa.

Myrdal G, 1963, Challenge of affluence, Pantheon Books, New York. 
Badanie dynamiki ubóstwa w Polsce z wykorzystaniem modeli analizy historii...

Okrasa W., 1999, Who avoids and who escapes from poverty during the transition. Evidence from Polish panel 1993-96, "Policy Research Working Paper", 2218, The World Bank, Research Development Group, Washington DC.

Okrasa W., 2000, Who are Poland's long-term poor? Household risk-managing capabilities according to panel data 1993-1996, "Statistics in transition", vol. 4, s. 841-882.

Panek T., 2001, Wymiary ubóstwa w Polsce w latach 1996-1999, "Wiadomości Statystyczne", nr 11, s. $37-55$.

Panek T., 2007, Ubóstwo i nierówności, [w:] T. Panek (red.), Statystyka społeczna (s. 258-298), PWE, Warszawa.

Panek T., 2011, Ubóstwo, wykluczenie społeczne i nierówności. Teoria i praktyka pomiaru, SGH, Warszawa.

Panek T., Podgórski J., Szulc A., 1999, Ubóstwo: teoria i praktyka pomiaru, Monografie i Opracowania 453, SGH, Warszawa.

Rada Monitoringu Społecznego, 2012, Diagnoza społeczna 2011: zintegrowana baza danych, www. diagnoza.com (data dostępu: 14.08.2012).

Rainwater L., 1981, Persistent and transitory poverty: a new look, Working Paper no. 70, Joint Center for urban Studies of the Massachusetts Institute of Technology and Harvard University, Cambridge: MIT, Harvard.

Rodgers J.R., Rodgers J.L., 1993, Chronic poverty in the United States, "The Journal of Human Resources", vol. 28, s. 25-54.

Rusnak Z., 2007, Statystyczna analiza dobrobytu ekonomicznego gospodarstw domowych, AE, Wrocław.

Shorrocks A.F., 1978, The measurement of mobility, „Econometrica”, vol. 46, s. 1013-1024.

Steele F., 2005, Event history analysis, NCRM Methods Review Papers, NCRM/004, ESRC Centre for Research Methods, http://eprints.ncrm.ac.uk/88/1/MethodsReviewPaper NCRM-004.pdf (data dostępu 20.10.2012).

Steele F., 2007, Multilevel discrete-time event history analysis, Centre for Multilevel Modeling, Graduate School of Education, University of Bristol, 13-14 September 2007, http://www.bristol.ac.uk/cmm/software/support/workshops/materials/eha.ppt (data dostępu 15.10.2012).

Steele F., 2011, Multilevel discrete-time event history models with applications to the analysis of recurrent employment transitions, "Australian \& New Zealand Journal of Statistics", vol. 53, s. 1-26.

Szukiełojć-Bieńkuńska A., 2008, Pomiar ubóstwa $i$ wykluczenia społecznego w urzędowej statystyce polskiej, [w:] I. Topińska (red.), J. Ciecieląg, A. Szukiełojć-Bieńkuńska, Pomiar ubóstwa. Zmiany koncepcji i ich znaczenie (s. 27-72), IPiSS, Warszawa.

Thorbecke E., 2003, Conceptual and measurement issues in poverty analysis, paper prepared for the UNU-WIDER „Conference on inequality, poverty and human well-being” 30-31 May 2003, Helsinki.

Topińska I., 2005, Dynamika i trwałość ubóstwa w Polsce i na Węgrzech w latach dziewięćdziesiatych, [w:] S. Golinowska, E. Tarkowska, I. Topińska (red.), Ubóstwo i wykluczenie spoteczne. Badania. Metody. Wyniki (s. 65-89), IPiSS, Warszawa.

Topińska I., 2008, Kierunki zmian w statystyce ubóstwa, [w:] I. Topińska (red.), J. Ciecieląg, A. Szukiełojć-Bieńkuńska, Pomiar ubóstwa. Zmiany koncepcji i ich znaczenie (s. 8-26), IPiSS, Warszawa.

Twisk J.W.R., 2010, Analiza wielopoziomowa - przykłady zastosowań. Praktyczny podręcznik biostatystyki i epidemiologii, SGH, Warszawa.

Willet J.B., Singer J.D., 1995, It's déjà vu all over again: using multiple-spell discrete-time survival analysis, "Journal of Educational and Behavioral Statistics" vol. 20, s. 41-67.

Yamaguchi K., 1991, Event history analysis, Applied Social Research Method Series vol. 28, Sage Publications, Newbury Park-London-New Delhi.

Yaqub S., 2000, Poverty dynamics in developing countries, Development Bibliography 16, Institute of Development Studies, Brighton. 


\title{
A STUDY OF POVERTY DYNAMICS IN POLAND USING DISCRETE-TIME EVENT HISTORY ANALYSIS MODELS
}

\begin{abstract}
Studies on poverty are based predominantly on cross-sectional analysis. Including a time dimension in the analysis allows us to better understanding the dynamics of poverty. In the long run, a unit (individual, household, family) can enter and exit poverty several times. An analysis of determinants of these events allows us to identify groups of households which are particularly likely to enter into poverty, and those with a high chance of exiting poverty.

The main aim of this article is to identify determinants of transitions into and out of poverty in Poland in 2000-2011. To achieve this, I use logit regression models for discrete-time event history analysis. I present two specifications of the model, one with number of years spent outside poverty and a second with additional selected socio-economic characteristics of household and household head.

The results of estimation suggest that the amount of time spent out of poverty or in poverty does not have a significantly effect, with the exception of one case, on the probability of a change in the status (in poverty/out of poverty). In the case of entries into poverty, including additional variables improves the model. I find that a change in probability of entry into poverty is significantly affected by age and education of household head, place of residence and labour force status of household. However, expanded model of poverty exits is worse than the base model. None of the included variables are statistically significant.
\end{abstract}

Key words: poverty dynamics, event history analysis, discrete-time models 